\title{
Miscellancea
}

\section{List Of Competed Master Dissertation January 2014 to December 2015}

Manandhar, Ranju. An insight into non-performancing assets of sbi bank ltd. MBS diss. 2070

Adhikari, Phul Phul. Performance and investment portfolio of insurance industry in Nepal. MBS diss. 2070

Shrestha, Samridhi. Credit management of the commercial bank in Nepal with special reference to Nepal investment bank ltd and bank of Kathmandu ltd. MBS diss. 2070

Gurung, Goma. Credit management .a case study of Everest bank ltd. MBS diss. 2070

Chapai, Hari Prasad. Impact of Pashchimanchal grameen bikas bank on women. Acase study of Pashchimanchal grameen bikas bank. MBS diss. 2070

Adhikari, Rejina. A study on profitability and liquidity analysis of Nepalese bank ltd.MBS diss. 2070

Bastola, Mina Kumara. A study on financial performance of bishal co-operative society ltd under framework of pearls. MBS diss. 2070

Tripathi, Deepak. mpact of pashimanchal grameen bikash bank on women empowerment in Lamachour VDC. MBS diss. 2070

Chapai, Surya. Micro finance practices and its impact on women. A case study of chhimeki bank ltd under lekhnath municipality ,Kaski. MBS diss. 2070

Sharma, Jagat Prasad. Role of micro finance institution on women empowerment. A case study of national educational and social development organization nesdo,Nepal. MBS diss. 2070

Poudel, Labchandra. Profit planning in commercial bank in Nepal. Acase study of NMB bank ltd.MBS diss. 2070

Aryal, Rajan. Profit planning and control. A case study of dairy development corporation. MBS diss. 2070

Bhatta, Kapil Babu. Profit planning and control. A case study of dairy development corporation. MBS diss. 2070

Neupane, Parbachan. Investment activities and performance of listed finance companies in Nepal. MBS diss. 2070

Bhandari, Pratikchhya. A comparative study on investment policy of subakamana multipurpose cooperative ltd and royal corporative ltd.MBS diss. 2070

Shakya, Suja. Credit management of Gandaki bikash bank and business development bank ltd. MBS diss. 2070

Kandel, Laxmi Sharma. Profitability and liquidity of Annapurna finance company ltd. MBS diss. 2070

Regmi, Deepak. Profit planning and control practice in nepalese development bank with reference to Shangrila development bank ltd. MBS diss. 2070

Parajuli, Khem Raj. Management budgeting and profit planning practice in nepalese commercial bank. acase study of Nepal investment bank ltd. MBS diss. 2070

Pokhrel, Nabaraj. Role of value add tax to national revenue collection. A case study of IRD office,Pokhara. MBS diss. 2070

Adhikari, Rita. Capital structure and profitability analysis of Machhapuchhre bank ltd. MBS diss. 2070

Gautam, Buddhi Ram. Dividend and stock prices. An empirical study. MBS diss. 2070

Koirala, Laxmi. Deposit collection and loan investment pattern of Machhapuchhre saving and credit c0operative ltd. MBS diss. 2070

Gurung, Kesh Bahadur. Credit management of finance company. A case study of Kaski finance ltd.MBS diss. 2070

Poudel, Yuvraj. Financial performance analysis of Pokhara royal-co-operative society ltd. In the frame work of pearls. MBS diss. 2070

Gurung, Antee. A study on credit management of Om finance ltd. MBS diss. 2070

Shakya, Rita. Credit risk management of Nepal investmet bank ltd and bank of Kathmandu ltd. MBs diss. 2070

Timilsina, Pitamber. A study on role of co-operative in poverty reduction.a case study shree khairenitar women development multipurpose co-operative ltd Tanahu. MBS diss. 2070 
Sharma, Jhalak Nath. Brand loyalty towards electronic appliances. MBS diss. 2070

Thakuri, Madan. A comparative study housing finance of fewa finance ltd and Kaski finane ltd.MBS diss. 2070

Rana, Aruan. Financial analysis of Putali Bazar municipality, Syangja. MBS diss. 2070

Chhetri, Ratna Bahadur. Study on tax revenue collection by local government of Nepal . A case study of Lekhnath Municipality. MBS diss. 2070

Panta, Shakuntala. Investment portfolio of Pokhara finance ltd. MBS diss. 2070

Subedi, Santosh. Comparative study of financial performance analysis of Kumara bank ltd and Everest bank ltd in the frame work of basal II. MBS diss. 2070

Neupane, Rudra Nath. A study on strategic planning of Nepal life insurance company ltd. MBs diss. 2070

Mandal, Jageshwar. Tax in Nepal special focus on exemption and deductions. MBs diss. 2070

Poudel, Loknath. Portfolio analysis and investment pattern of development banks in Nepal.comparative study with City development bank ltd and Garima bikash bank ltd.

Khanal, Binod. Impact of shreejana development centre in poverty reductions. A case study of Lamachour VDC in Kaski, Nepal.

Giri, Surya. Investment management of finance company in Kaski district . A comparative study of Api finance ltd and Kaski finance ltd. MBS diss. 2070

Aryal, Sushila. A study of hire purchase financing of Pokhara financing ltd Pokhara. MBS diss. 2070

Khanal, Shankar. Financial anilysis of con community saving and credit co-operative society ltd in the frame work of pearls. MBS diss. 2070

Thapa, Urmila. Liquidity management of commercial bank in nepal. With reference to Everest bank ltd and Standard chartered bank Nepal ltd. MBS diss. 2070

Timilsina, Nirmala. Micro credit program for women run by Muktinath bikash bank ltd. A case study of Lamachaur VDC. MBs diss. 2070

Khawas, Rima. Financial sustainability of Machhapuchre co-operative ltd. MBS diss. 2070

Tripathi, Anita. Impact of micro finance programme. A case study of Lahachowk VDC. MBS diss. 2070

Giri, Roshana. Financial performance analysis of City development bank ltd in the frame work of camels. MBS diss. 2070

Bhandari, Krishna Kumara. Deposit collection and loan distribution . A case study of Barahi saving and credit co-operative society ltd. MBS diss. 2070

Koirala, Basanti. Deposit collection and loan disbursement of Everest bank ltd. MBS diss. 2070

Tuladhar, Desh Bir. A study on working capital management practices. A case study of Saleways departmental stores pvt ltd. MBS diss. 2070

Banstola, Durga. Impact of micro finance on income generation rural women, a case study of Hemja VDC. MBS diss. 2070

Timilsina, Bishnu Maya. A study of credit management of Machhapuchhre bank ltd Pokhara. MBS diss. 2070

Subedi, Ram Maya. Business income tax reforms and its contribution to national revenue. MBS diss. 2070

Adhikari, Shiva Raj. A study on employment taxation ant its contribution to government revenue with reference to Pokhara valley. MBS diss. 2070

K.C, Bikash. Role of micro finance in women's empowerment. An empirical study in Kaskikot VDC under Utthan bank. MBS diss. 2070

K.C Usha. A study on deposit mobilization of Gandaki bikash bank ltd GBBL. MBS diss. 2070

Bastola, Ajaya Kumar. Cash dividend payment practice in nepalese commercial banks. A comparative study of SCB Nepal and SBI Nepal. MBS diss. 2070

Subedi, Sabina. Analysis of financial performance of Nepal SBI bank and Nabil bank ltd.MBS diss. 2070

Adhikari, Lila Dhar. Profit planning and revenue management of Nepal. MBS diss. 2070

Pandey, Deepak. Scope of tax planning under income tax act 2058 in Nepal. MBS diss. 2070

Karki, Mahendra. A study on export marketing of Nepalese readymade garment industry. MBS diss. 2070

Thapa, Tej Bahadur. Challengers of vat collection in Nepal on government effort in solving the problem. MBS diss. 2070 
Gautam, Rajendra Sharma. Non interest income and operating efficiency of commercial banks in Nepal. MBS diss. 2070

Shrestha, Junu. Financial analysis of Lekhnath municipality. MBS diss. 2070

Thapa, Shankar. A study of financial performance analysis of Fewa finance ltd in the frame work of CAMELS. MBS diss. 2070

Subedi, Dharma. Consumer behaviour towards buying motor bike in Pokhara valley. With reference to bajaj and hero honda brand motorbike. MBS diss. 2070

Poudel, Manju. Consumers attitudes towards internet banking service in Pokhara valley. MBS diss. 2070

K.C, Gauri Kumara. The market status of major national daily Nepali langaguage newspapers in Pokhara. MBS diss. 2070

Gurung, Jivan. Growth of capital market in nepal. With reference to BFLS. MBs diss. 2070

Bhattarai, Jeevan. Effectiveness of business promotion of United telecom ltd in Pokhara. MBS diss. 2070

Poudel, Barta Raj. Hire purchase financing. A study of Kaski finance ltd. Pokhara. MBS diss. 2070

Karki, Hari Bahadur. Status of microfinance in women uplifment .a study on micro finance programme of srijana development center in Hemja. MBs diss. 2070

Gurung, Huma Devi. A case study of deposit collection and mobilization of Kumari bank ltd. MBS diss. 2070

Baral, Sabita. Effectiveness of value added tax in Nepal. MBS diss. 2070

Timilsina, Laxman Parsad. A study on service of securities broker in Nepalese stock market. MBs diss. 2070

Shrestha, Sudha. A case study on financial performance analysis of Fishtail Hospital and Research center pvt. MBS diss. 2070

Koirala, Yoausha. Financial performance evaluation of Api finance ltd in the frame work of camels.MBS diss. 2070

Ghale, Krishna. A study of financial performance analysis of Laxmi bank ltd in the frame work of camel. MBS diss. 2070

Pun, Prem Maya. Deposit collection and mobilization. A case study of Nepal SBI bank ltd. MBS diss. 2070

Dhakal, Indira. A case study of export marketing of Nepalese readymade garment industry. MBS diss. 2070

Poudel, Ramchandra. Credit risk management .a case study of Nepal investment bank ltd. MBS diss. 2070

Gurung, Purna Kumar. Financial performance analysis of nepal sbi bank ltd in the frame work of basel II. MBs diss. 2070

Thapa, Dibas Singh. Credit card business and customer response.a study of NIBL,BOK and Laxmi bank ldt. MBS diss. 2070

Gurung, Sher Bahadur. Financial performance analysis of Om finance ltd in the frame work of CAMELS. MBS diss. 2070

Gurung, Dum Bahadur. Loan management.a case study of Kailash bikash bank ltd. MBS diss. 2070

Gurung, Krishna Maya. A companrative financial performance analysis of Subidha saving and cooperative ltd and Royal co-operative ltd. MBS diss. 2070

Ranabhat, Amrit. Impact of micro finace on women. A case study of NESDO, Nepal in Lekhnath municipality. MBS diss. 2070

Rana, Sakuntala. A comparative study on deposit collection, loan management and recovery pattern Annapurna finance company ltd and Om finance ltd Pokhara. MBS diss. 2070

Timilsina, Lekhnath. Profit planning in nepalese commercial blank. A case study of Nepal investment bank ltd. MBS diss. 2070

Bastola, Sirjana. Financial performance analysis of Fewa saving and credit co-operative society ldt in the frame work of pearls. MBS diss. 2070

Kharal, Krishna Parsad. Vat collection policy and practice. A case study of inland revenue office Pokhara. MBS diss. 2070

Shrestha, Bikal. A study on marketing planning and execution in deposit collection of Bishwa bank ltd. MBS diss. 2070 


\section{The Journal of Nepalese Bussiness Studies}

Dhital, Purushotam. A study on individual consumers buying behaviour towards laptops. MBS diss. 2070

Khadgi, Ram Parsad. Loan management of Shangirala development bank. MBS diss. 2070

Gurung, Bindu. A study on customar satisfaction of Kaski finance ltd. MBS diss. 2070

Pokhrel, Chandra Kanta. A study on deposit mobilization of Api finance ltd. MBS diss. 2070

Adhikari, Rammaya. Financial analysis of royal co-operative society ltd Syangja in the framework of pearls. MBS diss. 2070

Devi, Kalpana. A study on deposit mobilization loan disbursement and recovery of Pokhara finance company ltd (POFIL). MBS diss. 2070

Poudel, Saraswoti. A study on working capital management of unilever Nepal ltd. MBS diss. 2070

Koirala, Rajani. Capital adequacy of commercial bank. A study of Nabil,BOK and Sidhartha bank on based II implementation in Nepal. MBS diss. 2071

Gurung, Anju. Financial and academic performance analysis SOS Hermann Gmeiner School, Rambazar. MBS diss. 2071

Subedi, Pitamber. Sales planning and budgeting practice of Nepal oil corporation. MBS diss. 2071

Tripathi, Rajesh. Current position of Co-cola and Pepsi cola brand in Leknath municipality. MBS diss. 2071

Paudel, Ramesh. A comparative study on impact of interest rate in deposit collection and lending of Fewa finance ltd and Kaski finance. MBS diss. 2071

Gurung, Suk Bahadur. Risk and return behaviour analysis of common stock of insurance companies in Nepal. MBS diss. 2071

Adhikari, Samjhana. Share of public and private banks on deposit, loan advance and investment. MBS diss. 2071

Gurung, Jyoti Devi. A case study of deposit collection and loan disbursement of city development bank ltd. MBS diss. 2071

Poudel, Shambhu. Micro finance services effectiveness. A case study of RMDC ltd Nepal. MBS diss. 2071

Poudel, Dipendra. A cade study on lending practice of Kailsah bikash bank ltd. MBS diss. 2071

Devkota, Padammani. Financial performance analysis of Jay manakamana co operative society ltd in the frame work of pearls. MBS diss. 2071

Tilija, Tika. An analysis of brand loyalty while buying television. MBS diss. 2071

Dhakal, Shiva Kumar. A case study on credit management of Kaski finance company ltd. MBS diss. 2071

Shrestha, Mohan Bahadur. A study on capatil structure and performance analysis of Nepal investment bank ltd. MBS diss. 2071

Parajuli, Nita. Loan disbursement and recovery of finance companies under Nepal rastra bank directives. MBS diss. 2071

Thapa, Binod. Impact of T.V advertisement on consumer behaviour. With reference to cosmetic product. MBS diss. 2071

Poudel, Kalpana. An impact assement of micro finance for women. A case study of Pashichimanchal Grameen bikash bank, Hemja VDCc Kaski. MBS diss. 2071

Regmi, Maheshwor. Television advertising effectiveness of consumer non-durable products in Pokhara. MBS diss. 2071

Shrestha, Sushil. Financial performance analysis of Global Im bank ltd in the frame work of CAMEL. MBS diss. 2071

Prajuli, Komal. Impact of micro finance on women . A case study of Waling municipality Syangja undr Muktinath bikash bank ltd. MBS diss. 2071

Thapa, Nabin. Credit management of Gandaki bikas bank ltd and City development bank ltd MBS diss. 2071

Bhari, Sujit. Capital structure management of banks. A comparative study on Everest bank ltd,Nepal investment bank ltd, Nepal SBI bank ltd and Standard chartered bank ltd. MBS diss. 2071

Adhikari, Roshan. Financial performance analysis of premier insurance company ltd. MBS diss. 2071

Sharma, Sumita. Inventory management.a comparative study of Dairy development corporation and Sitaram gokul milk ltd. MBS diss. 2071 
Miscellancea; List Of Competed Master Dissertation ...

Sharma, Mamata. Comparative study on working capital management of Muktinath bikash bank ltd and Garima bikash bank ltd. MBS diss. 2071

Palikhe, Alina. A case study on lending practices of City development bank ltd. MBS diss. 2071

Bhandari, Karuna. A comparative financial performance evaluation of commercial banks under CAMELS frame works with reference to Nabil bank ltd and Himalayan bank ltd. MBS diss. 2071

Kunwar, Babita. Credit management of finance company . A case study of Kaski finance ltd. MBS diss. 2071

Dhakal, Santosh. Cash management of KBFPL. A case study on cash management of Karmacharya groups private limited. MBS diss. 2071

Wagle, Bishwo Prakash. Financial instruments in Nepal investors preferences and expectations.

Paudel, Sangita. Financial performance of premier insurance company ltd in the frame work of IRDA. MBS diss. 2071

Sharma, Narayan Prasad. Shree Luv- Kush milk's market position in Pokhara. MBS diss. 2071

Subedi, Shova. Financial performance analysis of Janasewa saving and credit co -operative society ltd. MBS diss. 2071

Lamichhane, Mahendra. Lond management and recovery. A case study of Nepal bank ltd. MBS diss. 2071

Thapa, Madhu. Financial health check up of Everest bank ltd and Kumari bank ltd in the frame work of BASEL II. MBS diss. 2071

Chalise, Ram Parsad. Analysis of cash flow. A case study on Nepal telecom corporation. MBS diss. 2071

Subedi, Biswas. A study on non-performancing assets of Nabil bank ltd and Machhapuchhre bank ltd. MBS diss. 2071

Pun, Khim Maya. Financial analysis of St.mary's higher secondary school, Nayagaun-15 Pokhara. MBS diss. 2071

Bastakoti, Bed Parsad. Television advertising and its impact on the buying behaviour of consumer with reference to Sunslick shampoo. MBS diss. 2071

Baral, Tejswi. Demographic analysis of cold drink users in Lekhnath Municipality . With special reference to Coca-cola and Pespi. MBS diss. 2071

Baral, Chandika. Analysis of financial performance of united finance ltd in the frame work of CAMEL. MBS diss. 2071

Poudel, Nabaraj Sharma. Deposit collection, loan disbursement and profitability of Pokhara based finance companies. MBS diss. 2071

Khadka, Ramesh. Lending policy and its effectiveness. A case study of bank of Kathmandu ltd. MBS diss. 2071

Giri, Balaram. Comparative analysis of bank of Kathmandu ltd and Everest bank ltd in the frame work of BASEL II. MBS diss. 2071

Shrestha, Bikram. Investment policy of development bank. A comparative study of Garima bikas bank ltd. MBS diss. 2071

Poudel, Rekha Kumara. An impact of micro finance program of Nirdhan utthan bank ltd for poverty reduction in Madi village of Chitwan district. MBS diss. 2071

Khadka, Bishal. Deposit mobilization of Kamana bikas bank and Muktinath bikas bank ltd. MBS diss. 2071

Bhattarai, Seela. Financial performance analysis under the framework of pearls of Dharmasthali saving and credit co-operative ltd, Pokhara -5, Kaski. MBS diss. 2071

Thebe, Shova Kumari. Financial performance analysis under the frame work of PEARLS of Nilgiri saving and credit co operative ltd pokhara 17, Kaski. MBS diss. 2071

C.K, Sudha Kumara. Impact of micro finance on women. A case study of Pokhara municipality ,Kaski under Muktinath bikas bank ltd. MBS diss. 2071

Acharya, Ganesh Prasad. Credit and liquidity management. With reference to Nepal investment bank ltd and Everest bank ltd. MBS diss. 2071

Nepal, Padma. A case study of micro credit programme on women entrepreneurs of Lekthnath municipality under rural urban partnership programme. MBS diss. 2071

Poudel, Pramesh. Impact of micro finance on women. A case study of Chhimeki bikas bank. MBS diss. 2071 
Marasani, Narayan. Income tax as sources of national revenue of Nepal. MBS diss. 2071

Poudel, Tanka Raj. Comparision of market positioning of Lux and Life boy soap in Pokhara. MBS diss. 2071

Poudel, Khem Raj. Analysis of right share practice in Nepal and its effect in market price. MBS diss. 2071

Bhandari, Rajesh. Role of tax revenue to strengthen then the local government. A case study of Lekhnath municipality corporation. MBS diss. 2071

Baral, Laxman. Sales planning practice and achievement of Nepal. MBS diss. 2071

Gurung, Samin. Impact of advertisement on the business of Pokhara finance ltd. MBS diss. 2071

Khanal, Anil. T.V. advertisement and its impact on buying behaviour of the consumer .With reference to tooth paste. MBS diss. 2071

Kunwar, Goma Devi. A study on advertising activities comparative study of Everest bank ltd and Kumari bank ltd. MBS diss. 2071

Neupane, Nirmala. Financial performance analysis of Pokhara finance ltd in the frame work of CAMELS. MBS diss. 2071

Karki, Durga. A study on financial performance of Machhapuchchhre bank ltd before and after the merger with Standard finance ltd. MBS diss. 2071

Ghale, Kanta. A atudy hire purchase financing trend and sector of investment of om finance ltd Pokhara. MBS diss. 2071

Bhandari, Shovakhar. A study on brand loyalty on consumers. Nokia, Samsung, Colors and Micromax mobiles. MBS diss. 2071

Tripathi, Durga. Comparative study on capital structure between Pokhara finance ltd and Fewa finance ltd. MBS diss. 2071

Baral, Bhoj Raj. A study on trend and problem of corporate bond market in Nepal. MBS diss. 2071

Bastola, Keshav Prasad. Financial performance analysis of fewa finance ltd in the frame work of CAMEL. MBS diss. 2072

Dhewaju, Sunil. A study on lending practices of Om finance ltd. MBS diss. 2072

Karki, Ekadashi. Non performing assets of Nepal bank ltd after management change. MBS diss. 2072

Khadka, Renu. Deposit collection and loan disbursement of Agricultural development bank main branch, Pokhara. MBS diss. 2072

Bajracharya, Juna. Comparative study on capital structure of Union finance ltd and Om finance ltd. MBS diss. 2072

Basyal, Mani Parsad. Capital structure ananlysis of commercial bank. A case study of Bank of Kathmandu and Himalayan ltd. MBS diss. 2072

Bhattarai, Puspa Kumarai. Profitability and liquidity analysis of commercial banks in Nepal. MBS diss. 2072

Gharti, Jit Bahadur Kaucha. Performance analysis of Nepalese commercial bank through cash flow analysis. With reference to MBL,LXBL and KBL. MBS diss. 2072

Thapa, Laxmi. A study on consumer buying behaviour while selecting T.V. brand. A study in Khairenitar Tanahun. MBS diss. 2072

Pangali, Ramprasad. Decision making behaviour of generation y consumers in the purchase of fashion apparel. A case study of Buddha bishal bazaar Mahendrapool, Pokhara.

Karki, Anup K.C. Effect of brand image on consumer buying behaviour of clothing product on Addidas brand. MBS diss. 2072

Wagle, Leena. Impact of microfinance on women . A case study of Janasewa saving and credit co-operatve society ltd Lamachour, Kaski. MBS diss. 2072

Karki, Pabita Basnet. Liquidity and profitability analysis of Nepalese commercial banks a comparative study of Nabil bank ltd and Machhapurchhre bank ltd. MBS diss. 2072

Bhandari, Mohan. Performance analysis of commercial bank in Nepal in the frame work of roe. MBS diss. 2072

Timilsina, Pawan Sharma. Socio-economic impact of remittance on Malyangkot village development committee. MBS diss. 2072 
Pun, Neeta. Employment income tax system of Nepal and it's contribution to revenue collection. MBS diss. 2072

Poudel, Santosh. Financial performance analysis of Agricultural development bank ltd in the frame work of CAMEL. MBS diss. 2072

Bastola, Sarmista. Financial performance analysis of Suryadarshan saving and credit co-operative ltd in the frame work of pearls. MBS diss. 2072

Ghimire, Sanjaya. Financial analysis of non performancing assects . A comparative study on Nabil and Mbl bank ltd. MBS diss. 2072

Subedi, Kamal. A study on the behaviour of nepalese index before and after the contstitutional assembly. MBS diss. 2072

Bhurtyal, Newton Parsad. Investment policy analysis . A case study of Machhapuchhre bank ltd. MBS diss. 2072

Neupane, Dilip. A study on consumer preference towards various brands instant noodles in Lekhnath city. MBS diss. 2072

Baral, Manju. Capital structure of Salt trading corporation ltd. MBS diss. 2072

Kandel, Gangadhar. Impact of micro finance programme on poverty alleviation . A case study of Chartare youth club. MBS diss. 2072

Shrestha, Deepa. Impact of micro finance on women. A case study of Deprosc development bank ltd in Lekthnath municipality Kaski. MBS diss. 2072

Pokhrel, Guru Prasad. A study of income tax on investment in Nepal and its impact on revenue collection. MBS diss. 2072

Poudel, Surya. Financial performance analysis of muktinath bikash bank ltd in the frame work of CAMEL. MBS diss. 2072

Dhakal, Umesh. Awereness of taxpayers towards business taxation . A case study of Pokhara Sub metropolition city. MBS diss. 2072

Sigdelm, Padam Raj. Financial performance analysis of Golden saving and credit co-operative ltd in the frame work of pearls. MBS diss. 2072

Thapa, Rajesh. Credit risk management of Joint venture banks of Nepal. MBS diss. 2072

Poudel, Laxmi. An impact of dividend policy of market price of shares. MBs diss. 2072

Adhikari, Shiva Ram. A case study of financial performance analysis of Kailash bikash bank ltd in the frame work of CAMEL. MBS diss. 2072

Sapkota, Sanaya. A study on role of merchant banking in primary market. With ref . to citizen investment trust and nidc capital market. Ltd. MBS diss. 2072

Shrestha, Sahana Bataju. A study of financial analysis of Shangrila development bank ltd and Kamana bikash bank ltd. MBS diss. 2072

Thapa, Sunita. A study on interest rate structure and impact on deposit and lending of Fewa finance ltd and Pokhara finance ltd. MBS diss. 2072

Dhungana, Bal Krishna. Inventory management in Nepalese manufacturing industries. A study of him shree foods pvt ltd. MBS diss. 2072

Bhandari, Bishworaj. Financial performance analysis of City development bank ltd. MBS diss. 2072

Puri, Deepak. Financial ananlysis of Bishal co operatives in the frame work of pearls. MBS diss. 2072

Adhikari, Dhruba. Impact of micro finance programme for women development. A case study of small farmer agriculture co-operative ltd, Nirmal Pokhari VDC, Kaski. MBS diss. 2072

Thakuri, Devi Hamal. Credit management of development bank. A case study of Bishwo bikas bank ltd. MBS diss. 2072

Gurung, Manita. Risk and return analysis of Nepalese insurance company. MBS diss. 2072

Adhikari, Hari Chandra. A comparative analysis of loan portfolio of financial institutions. With refrence to Kailash bikash bank ltd and Pokhara finance ltd. MBS diss. 2072

Magar, Raju Bhujel. Inventory management in Unilever Nepal ltd. MBS diss. 2072 